\title{
Investigation into a Link between Students' English Reading Speed and Reading Comprehension Achievement: The Case of Indonesian EFL Student Teachers
}

\author{
Andri Pratama \\ andripratama@gmail.com \\ An English Teacher at SMP 23 Baturaja, South Sumatera, Indonesia
}

\begin{abstract}
The aims of the study were to look at the link between English as a foreign language (EFL) student teachers' reading speed and reading comprehension achievement and whether it influenced their reading comprehension achievement or not. The population of the study was 583 active EFL student teachers in one English Education Study Program at an Indonesian state Islamic University. By using purposive sampling technique, there were 87 students involved as participants in this study. The data were gained by using two kinds of tests, reading speed test and reading comprehension test. Descriptive statistics, Pearson Product Moment Correlation was employed to analyze the data. From the data analyses, it was found that the correlation between EFL student teachers' English reading speed attitude and their reading comprehension achievement did not exist. As the result, the second problem was eliminated. In short, reading speed did not have any relation to reading comprehension achievement.
\end{abstract}

Keywords: English reading speed, reading comprehension achievement

\section{Manuscript submitted: March 12, 2019 \\ Manuscript revised: April 4, 2019 \\ Accepted for publication: May 16, 2019}

\section{Introduction}

English is a global language. As stated by Sharifian (2008), English is used by people around the world for many activities in life. As a global mean, people use English for many activities, such as in politics, economy, science, education, and culture. In addition, Abrar, Mukminin, Habibi, Asyrafi, Makmur, and Marzulina (2018) said that English was used in every corner of the world as a medium to interact among people from different cultural, ethnic, and social backgrounds. Julie and Deborah (2009) explains that English is used both in a global sense for international communication between countries and in a local sense as a language of wider communication within multilingual societies. Along with the rapid use of English as an international language, therefore, we cannot ignore learning English. It is supported by Abrar et al. (2018) who stated that In Indonesia, an incredibly diverse and multicultural country, English is regarded as one of the most popular foreign languages.

English language itself can have an effect on technological progress and science in the future as explained by Astrid (2011), who said that it could be realized in learning English if it is neglected, the value of the knowledge and the technology on its own role will be decreased. It can be concluded that as technology grows rapidly, the use of English as an international language that can be used to interact with the world community is urgently needed.

Moreover, in learning English, there are 4 skills that need to be learned, those are reading, listening, writing and speaking. According to Harmer (2001), listening and reading skills part are regarded as receptive skills while speaking and writing skills are considered to be 
productive skills. Those are the language skills taught at schools, courses or other educational institutions either formal or informal. Putra and Marzulina (2014) add that reading plays a great role in understanding a written statement accurately and efficiently to get the knowledge students want to learn. It is also reinforced with the statement of Lestari and Holandyah (2016), in regard to reading, it will help the reader to improve their knowledge. Reading is an activity that focuses on the ability to identify written words, recognize the meanings, and comprehend an author's message (Mawadda, 2015) so that it can be inferred that reading is an important skill for people. Through reading skills, it might help the learners to read a text in many forms which contribute for a great deal in their life such as gaining success at school, university or other educational institutions.

Since we have realized the importance of reading, students sometimes in reading activities find some obstacles that can slow them down in reading. The majority of students tend to plough through a written print. They struggle in reading word-by-word they do not know. This situation makes students more difficult to grasp the meaning of what they read and causes them to get stuck on single words which may not be absolutely essential to the general understanding of a text. Normally, readers do not read every book at the same speed. They read a news paper, for instance, much more rapidly than physics textbook or other scientific books. This inflexibility, in fact, wastes students' capacity and causes them feeling of resentment for the reading activity. Finally, people should have an ability to read faster in order to receive information given to them. Speed reading is designed by Evelin Wood in 1958. It is a technique that is very important to learn in order to know important information quickly. Fraser (2004) states that reading speed is estimated as being an accurate measure of reading fluency it is used. Shortly, in this case speed reading is one of the capabilities that can be used to understand and quickly conclude upon what has been read in a text in line that the ability of reading speed is important to help people in facing the huge improvement in the era of information nowadays.

Grievously, the ability to read quickly itself has a weakness in its own terms. There are such factors that affected, so that fast reading itself can be an obstacle or hurdle for its readers. This is similar to what is conveyed by Nordquist (2016) who argues that reading speed is determined by a number of factors, including a reader's purpose and level of expertise as well as the relative difficulty of the text. In his opinion, the purpose of the reader refers to the usefulness of for what the reader is reading it. In this case, if the reader reads the text related to the thing that entertain, then he will quickly and easily understand the contents of the reading he read. Thus, it is inversely proportional if he reads something he does not like. Furthermore, the level of expertise in that point refers to how much the reader can read and understand the content of the reading which is also influenced by the vocabulary as well as the grammar presented in the reading. At this stage, grammar and vocabulary play their part in influencing the difficulties in rapid reading itself. Furthermore, Nation (2009) emphasized that the difficulty of the text is affected by the vocabulary, grammatical constructions, discourse, and background knowledge. In conclusion, the difficulty caused by the vocabulary level, grammatical construction, or discourse is proportional to the background of the student's ability level as much as he can understand the contents of the text. For this reason, the most emphasized thing in how quickly they can read should be equal to how much students understand the content of reading.

Therefore, since we know how fast a student can read a text, it will be useless if he fails to understand and conclude what he got from text. For that case, Courbron (2012) shows that reading speed and reading comprehension have rapidly been shown to have a strong connection. Nuttal (1982) mentioned that reading speed and reading comprehension are tightly related factors. In addition, Grellet (1981) also explained the phenomenon which students read too slowly will easily get discouraged, they will also tend to stumble on unfamiliar words and fail to grasp the meaning. According to those explanations above, it can be inferred that reading speed 
and reading comprehension play an important part on reading. When students tend to read the text too slowly and too preoccupied with the meaning of the word for word that they read, they will fail to interpret the whole sentence as the meaning.

Based on the test conducted to 10 EFL students who were chosen randomly. The result showed that their reading speed scores were around 200-250. Somehow, the score ranges of the students were as good as the range level of college students as suggested by Beale and Mullan (2008) which is 250 WPM (words per minute). Moreover, some of them were considered as having bad reading. Somehow, some of them had a good reading score but not a good reading speed. In contrast, even some of them had a quite good reading speed; their comprehension was not as expected. It indicated that they just merely read and not comprehend the passage they read. Considering these problems above, I was interested in doing research about the correlation between students' reading speed and reading comprehension achievement of the English Education Study Program of one Indonesian State Islamic university.

\section{Literature Review}

\section{Reading}

According to Misa (2014), reading is an activity to get information from a text which is in the process of reading, reader must understand the implicit and explicit meaning from the text. Moreover, Yusthi (2016) explained that reading is an activity to making sense that involving interaction between background knowledge of reader and the printed word. From previous definitions above, it can be infered that reading is an cognitive and affective process in decrypting and understading written text to get the message from the writer.

\section{Reading Speed}

Reading speed is the rate at which a person reads written text (printed or electronic) in a specific unit of time. Reading speed is generally calculated by the number of words read per minute. Furthermore, reading speed constitutes in combination with reading comprehension, the two crucial components of skilled reading. Its significance lies in its role in determining the extent of readers' fluency. When reading, this can mean absorbing very spesific details or merely grasping a general concepts, personal understanding is the key.

In order to measure the students reading speed, Arab (2009) mentioned that a student's reading rate is calculated by dividing the number of words in a text by the total amount of reading time, it is recorded in words per minute.

\section{Reading speed categories}

The EFL category was divided into talker, average reader, above average reader, and speed reader. Moreover, readers fall into these categories where speed is concerned: 1 to 200 WPM: You're a talker. You read one word at a time at about the same speed as you talk and you may move your lips when you read. 200 to 300 WPM: You're an average reader, one who probably doesn't enjoy reading as a hobby. 300 to 700 WPM: You're an above average reader who can read groups of words in a single glance, recognizing and reading phrases in sentences quickly. 700+ WPM: You're a speed reader. You're adept at reading 10 to 16 words at a glance.

\section{Reading comprehension}

Susiana (2016) explains that reading comprehension means understanding and remembering the ideas you find as you read. Reading is not only to get information but it needs understanding and comprehension to get some points from the text. In reading process, comprehension is one of the reason readers read text. Nation and Angel (2006) argued the ultimate goal of reading is to understand what has been read. It means that, comprehension is a 
goal of reading activity which involves the process of making sense of words, sentences, and connected texts.

\section{Methods}

\section{Research design, research site and participants}

In this study, the quantitative design was used in which the researcher administered a survey to the sample or the entire population of the people to describe the attitudes, opinions, behaviors or characteristics of the population. This study was conducted in one English Education Study Program at an Indonesian State Islamic University who had already taken all the reading courses. To choose the sample, I used purposive sampling technique since purposive sampling allowed the studyer to specify the characteristics of a population of interest and then try to locate individuals who had those characteristics. Somehow, in order to know the students' reading comprehension achievement, a group of students who had already taken all the reading courses (Reading I, Reading II, Reading III, Reading IV) from the population was considered as the sample. Therefore, all four classes of the sixth semester students were considered as the subject of this study. The total number of sample was 87 students involved.

\section{Data collection and analysis}

In collecting data, there were two kinds of instrument. They were reading speed test and reading comprehension achievement. Reading speed text test was taken from Gerald and Vivianne Mosback' book entitle Practical Faster Reading. Reading speed test text consisted of one passage which was provided in order to determine the speed of students reading. Actually, the passage contained approximately 541-word readings. Then, the result of the speed text test of students' reading was counted by using words per minute's formula in order to know the students' reading rate.

Furthermore, to measure students' reading comprehension achievement, I also used reading speed comprehension test from Gerald and Vivianne (1976) entitled Practical Faster Reading, since the reading comprehension achievement test was used in order to obtain the level of students' comprehension based on the text that related to those who had already read. The reading comprehension achievement test consisted of twenty multiple choice questions (MCQ).

Before the test was administered, the readability, validity and reliability test had been considered. Firstly, the readability test was conducted by using online readability test which had been accessed from (wmw.readabilityformulas.com), then the result showed that the text on the level fairly difficult to read. Actually, the readability text test was on the level Fairly Difficult to Read which Flesch-Kincaid Reading Ease Score was on 59, the text was considered available for college learners. In addition, since Kong (2006) said that an instrument in which its reliability and validity has already been proven from the previous study. Hence, in this study, the validity and reliability for both of the test were not conducted because the test was ready-made. After the test was administered, the normality and linearity as requirement for hypothesis testing was checked.

\section{Data analysis}

In data analysis, there were two kinds of instrument need to be analyzed: reading speed text test analysis and reading comprehension achievement analysis. The reading speed was classified into four levels: talker, an average reader, above average reader, and speed reader. The score from reading speed was analyzed by using SPSS Statistics program to get the result of frequency data and descriptive statistics. In descriptive statistics, number of sample, the score of minimal, the score of maximal, mean, standard deviation, and standard error of mean were obtained. 
After that, reading comprehension achievement was analyzed. There were 20 items of the questions; each correct answer was multiplied by 5 to make the highest score reach 100 . The result was classified into two categories. Those students who reached the score above $70 \%$ was classified as good comprehension and for those who got the score below $70 \%$ was classified as bad comprehension.

\section{Findings}

\section{The result of students' English reading speed}

After the study was conducted, the table below showed that the reading speed of the participants (WPM) was grouped by their categories which were the sixth semester students of the English Education Study Program of one Indonesian State Islamic university. There were 49 students whose reading speed were about 1-200 WPM, 38 students who were average reader with reading speed which was about 200-300 WPM. However, there was no student in the range of 300-700 and above 700 WPM. The percentage of the reading speed of sixth semester English Education Study Program of one Indonesian State Islamic university, it could be seen in table below:

Table 1. Students' reading speed categories

\begin{tabular}{clccc}
\hline No & Category & WPM Category & Students & $\begin{array}{c}\text { Percentage } \\
\text { (\%) }\end{array}$ \\
\hline 1 & Talker & 1 to 200 WPM & 49 & 56 \\
2 & Average Reader & 200 to 300 WPM & 38 & 44 \\
3 & Above Average Reader & 300 to 700 WPM & - & - \\
4 & Speed Reader & $700+$ WPM & - & - \\
\hline \multicolumn{2}{c}{ Total } & & 87 & 100 \\
\hline
\end{tabular}

Thus, based on the table, there were 49 students who reached Talker category (56\% from the data) and 38\% students who reached Average Reader category (44\% from the data). However, there was no student in the range of 300-700 and above 700 WPM. Somehow, the score range of the students were as good as the range level of college students since the score word per minute of the EFL students was on the range 100-300 WPM. Moreover, the total number of the sample was 87 students, the minimum score of the students' English reading speed was obtained 108 WPM while the maximum score was 277 WPM. The mean score was 197,66 with the standard deviation was 31,84 .

\section{The result of students' reading comprehension achievement}

The result of descriptive statistics analysis of reading comprehension achievement was shown in the table below. For each category, 67 students had good reading comprehension achievement, and 20 students had bad reading comprehension achievement.

Table 2. Distributions of students' reading comprehension achievement

\begin{tabular}{ccccc}
\hline No & Score Range & Category & Number of Students & $\begin{array}{c}\text { Percentage } \\
\mathbf{( \% )}\end{array}$ \\
\hline 1 & At least 70\% & Good Comprehension & 67 & 77,1 \\
2 & Below 70\% & Bad Comprehension & 20 & 22,9 \\
\hline \multicolumn{2}{c}{ Total } & 87 & \\
\hline
\end{tabular}




\section{Result of normality test}

The data are concluded normal if $\mathrm{p}>0.05$, and then, if $\mathrm{p}<0.05$. It showed that the distribution of the data was not normal. Kolmogorov-Smirnov was used to see the normality. The results of the data showed that each variable were all normal, so it could be continued for further data analysis. Reading speed and reading comprehension achievement were concluded that significant value for the reading speed was about 0.2. Since the result of the reading speed was greater than 0.05 , it meant that the students' reading speed was normally distributed. Thus, the result of the reading comprehension achievement of the students was greater than 0.05 which was 0.6 It indicated that the students reading comprehension achievements were distributed normal. After all, the data of the English reading speed of the students and their reading comprehension achievement were normally distributed, thus the data was processed to correlational analysis.

\section{The correlation between students' English reading speed and students' reading comprehension achievement}

At this stage, this section answered the first research problem by analyzing the result of students' English reading speed test and their reading comprehension achievement.

Table 3. Correlation between Students' English reading speed and reading comprehension achievement

\begin{tabular}{llrr}
\hline & & Reading_Speed & Reading_Comprehension \\
\hline Reading_Speed & Pearson & 1 & .031 \\
& Correlation & & .778 \\
& Sig. (2-tailed) & 88 & 87 \\
& N & .031 & 1 \\
Reading_Comprehension & Pearson & .778 & 87 \\
& Correlation & 87 & \\
& Sig. (2-tailed) & & \\
& $\mathrm{N}$ & & \\
& & &
\end{tabular}

Based on the table above, the result of the data which was shown by using Pearson Product Moment Correlation Coefficient indicated that correlation coefficients of both variables were 0.031 , the level of correlation was very slight and the correlation was in the negative direction hence the correlation coefficient almost reached zero point. Hence, it also inferred that approximately there was no correlation between the variables. Moreover, from the statistical analysis, it was also unveiled that the p-value was .778 which was greater than $.05(.778>.05)$. Thus, these scores explicitly indicated that there was no correlation between students' English reading speed and their reading comprehension achievement. Additionally, there was no correlation between students' English reading speed and their reading comprehension achievement. Students' reading speed were analyzed and correlated with the reading comprehension achievement by the same formula, Pearson Product Moment Correlation Coefficient. Still, the same results were obtained, then there was no significant correlation.

Therefore, since there was no correlation between the variables, there was no need to continue to do regression test which aimed to find out the contribution of reading speed to students' reading comprehension. Hence, the answer for the second question was that there was no influence of reading speed to students' reading comprehension. 


\section{Discussion}

Based on the result of Pearson Product Moment correlation, it was found that there was no significant correlation between students' English reading speed and reading comprehension achievement of undergraduate EFL students of one Indonesian State Islamic university. It could be assumed that reading speed had no relation to their reading comprehension achievement. This finding was in line with Chang and College (2010). The correlation between reading speed and reading comprehension achievement did not exist. Somehow, this finding was on contrary to the findings of Humairah, Komariah, and Inayah (2017). They found a significant correlation between students' reading speed and their reading comprehension students of class XII at SMAN 3 Banda Aceh. Eventhough, some researchers found that reading speed was correlated to reading achievement, this study believed that reading speed did not give any contribution to reading comprehension achievement.

Moreover, although from the beginning of the semester the study participants had been involved in English reading book and assignments or explore English reading materials from printed textbook, online media, English environment and their social network, as the result those reading materials did not always support their reading speed and their reading comprehension achievement. I claimed that there were other factors that influenced their reading comprehension. Since reading was an activity to get information from the text, when reading it must be understood the implicit and explicit meaning from the text. Perfetti, Yang and Schamalhoffer (2008) explained that some readers fail to effectively integrate words with prior context. Furthermore, this integration failure may involve word processing - not decoding, but the ability to link word meanings appropriately in sentence contexts. The successful readers indicated that they were more efficient at gaining unfamiliar word meanings from texts because they had a greater existing vocabulary, more experience using context clues, and greater background knowledge since difficulty of the text was affected by the vocabulary, grammatical constructions, discourse, and background knowledge. In other words, the lack of students' vocabulary was decreased of the students' comprehension.

Moreover, the other reason to support this finding was students' reading ability. The students who read faster did not get the higher comprehension as well as their fast reading rate, so that is why if somebody read fast with 450 words per minute, but he cannot comprehend the text, or if he can comprehend the text but he reads very slowly, he cannot be said having a good reading ability. When reading absorbing very spesific details or merely grasping a general concepts, personal understanding is the key. Other reasons, Wolley (2011) mentioned that students' attitudes to reading had a considerable bearing on their persistence and success in reading. Moreover, he also added that students with reading difficulties often had negative affective and motivational variables that impacted upon the reading process. As an instance, many less skilled readers had experienced failure over a considerable period of time, leading to low levels of future expectations and a reduced motivation to try. If readers involved in the selection of texts and focused on their reading tasks, their approach to reading should be free from extraneous and competing distractions.

Actually, it was important for learners to supervise their own learning process, Hansen (2016) explained that it might be valuable for teachers to be able to distinguish the learners with good opportunities to become high proficiency readers from those who were likely to struggle more with reading comprehension. This emotional reaction also contributed to improve attitudes, engagement and enjoyment with reading. However, it is noted for a text to be motivating and involving, it is desirable that it was not be too difficult or too easy while at the same time providing choice related to the interests of the reader.

Additionally, in my point of view, others factors also had a big role in influencing reading comprehension achievement of the students through reading speed since the reading speed was 
looked on the rate of the reader. Moreover, Long and Doughty (2009) explained that the pressure to go faster was a source of stress. Such pressure reduced the enjoyment that learners got from reading. It was best to see the skill of reading faster as providing a wider range of choices for a reader. Sometimes, the fastest of the reading depended on what readers' need. Being able to make the choice was an advantage. Readers might have different goals what their needed in their reading process, some readers read just for fun and others read for specific information which depended on the readers' reading material.

\section{Conclusions and Recommendations}

From the data analysis, I concluded that there were three conclusions which were drawn in this study based on the findings and interpretations. From the data analysis, the p-value was .778 which was higher than .05. As the result, it was found that there was no statistically correlation between students' English reading speed and their reading comprehension achievement. Second, the correlation did not exist between students' English reading speed and their reading comprehension achievement, the studyer did not continue this study to the second research problem. So, it was worthed that students' English reading speed did not give any influence to students' reading comprehension achievement. Consequently, it could be inferred that students with bad reading speed were not guaranteed that they were bad in reading comprehension achievement. In that case, it was other factors that had relation in pursuing students' English reading speed and reading comprehension achievement.

Based on the conclusions above, the suggestions in this study were provided for the students, lecturers, and other researchers who were interested in the future research. First, to the students, since reading ability of the students was important, they have to be aware and have to explore more on their own role so they could strengthen their strangeness in many aspects of their lives. Second, to the lecturers, especially in English Education Study Program, it was suggested that all the lecturers needed to consider the solution to develop students' reading comprehension achievement. This study revealed the current conditions and teaching learning outcomes especially in reading subject at English Education Study Program. Finally, for future researchers who had interest in this subject, reading speed was actually quite challenging research, since it was the first project. I suggested that other future researchers need to promote the local and target language cultural contents in reading text for students who learnt English as a foreign language as like Indonesia.

\section{References}

Abrar, M., Mukminin, A., Habibi, A., Asyrafi, F., Makmur, M., \& Marzulina, L. (2018). "If our English isn't a language, what is it?" Indonesian EFL Student Teachers' Challenges Speaking English. The Qualitative Report,23(1), 129-145. Retrieved from https://nsuworks.nova.edu/tqr/vol23/iss1/9

Arab, O. (2009). Enhancing reading speed for EFL classes: The case of first year LMD students (Master's thesis). University of Constantine, Aljir, Aljazaere.

Astrid, A. (2011). Pembelajaran tata bahasa inggris secara komunikatif dengan penyajian induktif dan pengintegrasian keterampilan berbahasa: Studi kasus dikelas bahasa inggris I di IAIN Raden Fatah Palembang. Jurnal Ta'dib, 16(02), 175-206.

Beale, A. M., \& Mullan, P. (2008). The complete idiot's guide to speed reading. New York, NY: Alpha.

Chang A. C. S., \& College H. W. (2010). The effect of a time reading activity on EFL learners: Speed comprehension, and perception. Foreign Language Journal, 22(2), 284-303. Retrieved from http://www.eric.ed.gov/ERICwebportal/RecordDetai?accno=EJ901548 
Courbron, C. (2012). The correlation between the three reading fluency subskills and reading comprehension in at-risk adolescent reader (Unpublished Master's Thesis). Lynchburg, VA: Liberty University.

Fraser, C. A. (2004). Reading fluency in a second language. The Canadian Modern Language Review. 61(1), 135-160

Gerald, M., \& Vivienne, M. (1976). Practical faster reading. London, England: Cambridge.

Grellet, F. (1981). Developing reading skills. London, England: Cambridge University Press.

Hansen, J. E. (2016). Masteropgave: Reading comprehension. Master Fremmedspråki skolenAvdeling for okonom, 24(5), 1-69.

Harmer, J. (2001). The practice of English language teaching. London, England: Longman.

Humairah, S. E., Komariah, E., \& Inayah, N. (2017). The correlation between students' reading speedand their reading comprehension. Research in English and Education (READ), 2(4), 144152.

Julie \& Deborah. (2009). American English: History, structure, and usage. Cambridge University Press. Retrieved from http://www.cambridge.org.

Kong, A. (2006). Connection between L1 and L2 readings: Reading strategies used by four Chinese adult readers. The Reading Matrix, 6(2), 19-45.

Lestari, A., \& Holandyah, M. (2016). The correlation between reading attitude and writing achievement of the eleventh-grade students of SMA Muhammadiyah 6 Palembang. Jurnal Pendidikan dan Pengajaran. 3(1), 45-52. http://jurnal.radenfatah.ac.id/index.php/edukasi/article/view/627/553.

Long, M. H., \& Doughty, C. J. (2009). The handbook of language teaching. New Jersey, NJ: WillyBlackwell.

Mawadda, M. (2015). Teaching reading comprehension to the eighth-grade studentsof SMP Negeri 12 Palembang by using story pyramid. Jurnal Pendidikan dan Pengajaran, 2(1), 55-67.

Misa, M. (2014). The use of guided metacognitive strategy to improve students' reading comprehension. Jurnal Pendidikan Humaniora, 2(4), 304-310.

Nation, K., \& Angell, P. (2006). Learning to read and learning to comprehend. London, UK: Review of Education.

Nation, I. S. P. (2009). Teaching ESL/EFL reading and writing. New York, NY: Routledge.

Nordquist, R. (2016, September 20). Reading speed: Glossary of grammatical and rhetorical terms [Blog Post]. Retrieved from https://www.thoughtco.com / reading-speed-1691898.

Perfetti, C., Yang, C. L., \& Schamalhoffer, F. (2008). Comprehension skill and word-to-text integration processes. Applied Cognitive Psychology, 2(22), 303-318.

Putra, H., \& Marzulina, L. (2014). Teaching reading comprehension by using content-based instruction (CBI) method to the second-year learners at MTS Al-Furqon Prabumulih. Jurnal Edukasi Pendidikan dan Pengajaran, 2(2), 185-197.

Susiana, S. (2016). Improving students' reading comprehension by using REDW (read, examine, decide, and write) strategy to the tenth-grade students of MA Al-Muawwanah Gunung Megang Muara Enim Summatera Selatan. Jurnal Pendidikan dan Pengajaran, 3(1), 63-71.

Sharifian, F. (2008). English as international language (challenges and possibilities). Australian Review of Applied Linguistic, 31(3), 1-16.

Wolley, G. (2011). Reading comprehension: Assisting children with learning difficulties. Springer Science and Business Media. Retrieved from: http://www.springer.com/978-94-007-1173-0

Yusthi, E. (2014). Teaching reading comprehension in recount text by using zooming in and zooming out (ZIZO) strategy grade students of SMP Sriguna Palembang. Jurnal Edukasi Pendidikan dan Pengajaran, 2(2), 132-146. 